ROMAN GASKA

ZBIGNIEW WOLNY

MARIUSZ MYRLAK

MARCIN KRUK

TOMASZ KARPIEL

\title{
The improvement of work safety and the functionality increase of operating the mine shaft hoist at the Tauron Wydobycie S.A. Z.G. Sobieski
}

\begin{abstract}
The article presents information on changes to the mine shaft hoist in the cage compartment of the "Sobieski III" shaft of Tauron Wydobycie S.A. A separate control unit based on MENTOR thyristor converters was installed in the excitation system of the drive motor and control generators, which allowed the replacement of systems that were difficult to operate, e.g. electromechanical amplifier (amplidyne) and the machine exciter of the hoist motor. Additionally, in order to stabilize the speed (especially during revision works in the shaft), the system of setting speed levels of the hoisting machine has been modified. Speed adjustment is realized by a follow-up speed control system built on the basis of a digitally controlled MENTOR reverse converter.
\end{abstract}

Key words: mine shaft hoists, modernization, hoisting machine, safety, control system

\section{GENERAL CHARACTERISTICS}

The presented hoisting machine is an element of a mine shaft hoist: a dual-vessel, cage hoist, intended for human travel, material, and output transport, installed in the room at the shaft top. The hoisting machine is manually controlled and cooperates with the shaft signalling and communication device. The hoisting machine is driven by a separately excited DC motor, powered from an electromechanical control generator and operating in the Leonard system. The direction of the motor rotation is changed by altering the direction of the excitation current of the control generator [1].

The control rod on the hoisting machine control stand is connected to a mechanical travel controller, a depth gauge - a shaft control panel and an induction setter. The rudder deflection angle is mechanically limited by cams as a function of the position of the cages [2]. The overall diagram of the speed setting system is shown in Figure 1.

Irregular changes in resistance in the speed selection system, as a result of the external temperature (the result of the aging of elements), caused a change in the set point which, combined with the inertial nature of the control system, resulted in:

- unstable operation,

- speed overshoot,

- non-linearity of the travel diagram.

All this resulted in the travel parameters being lower than the concession ones, which extended duration of the travel cycle. The economic effect of such a state was noticeable due to the reduction in production.

Figure 2 shows an example of a randomly selected machine operation registration. There are visible states of unstable operation consisting in overshoots and a non-linear travel diagram. 

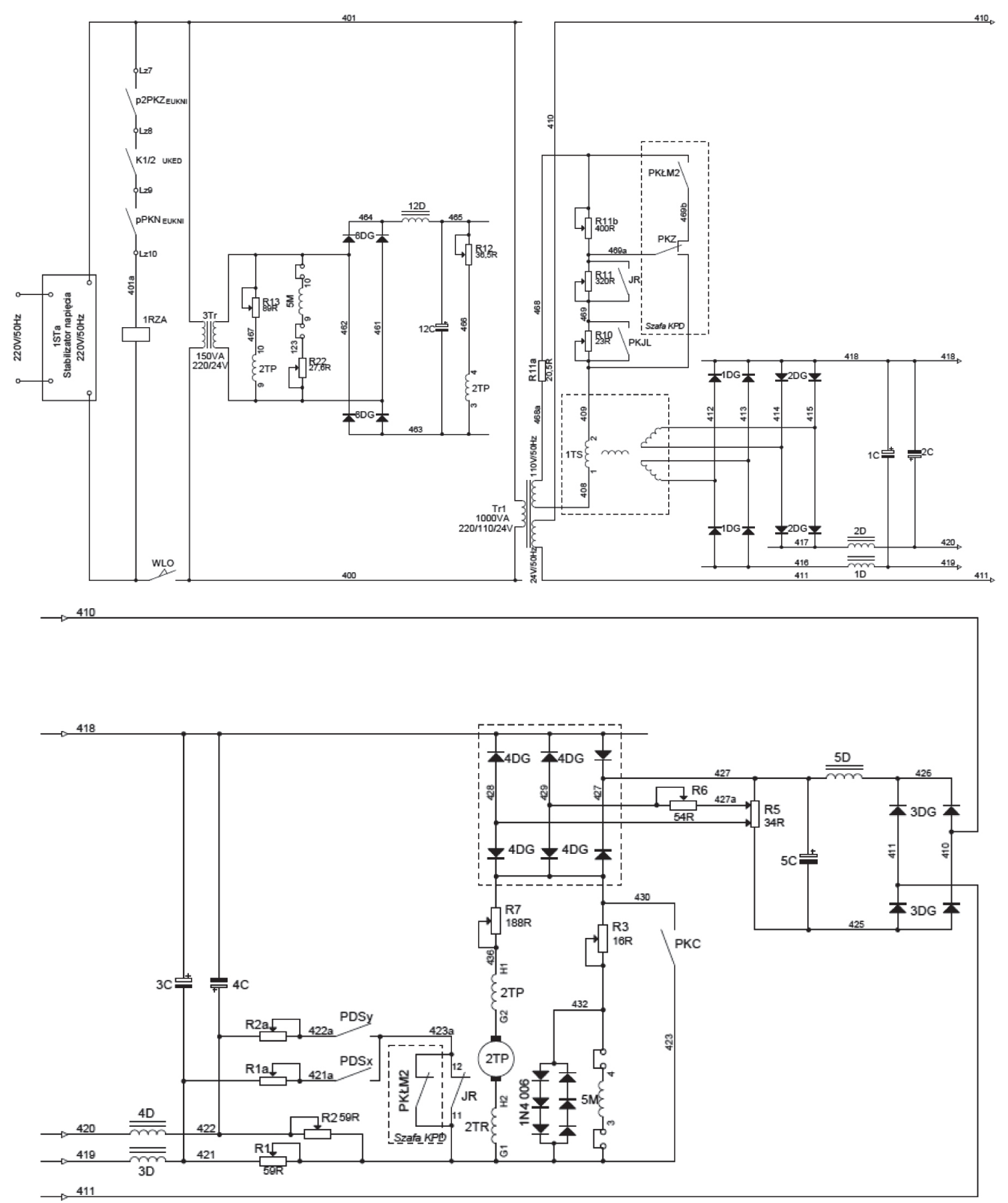

Fig. 1. Block diagram of the speed setting system with the system of selecting the maximum speed [2]

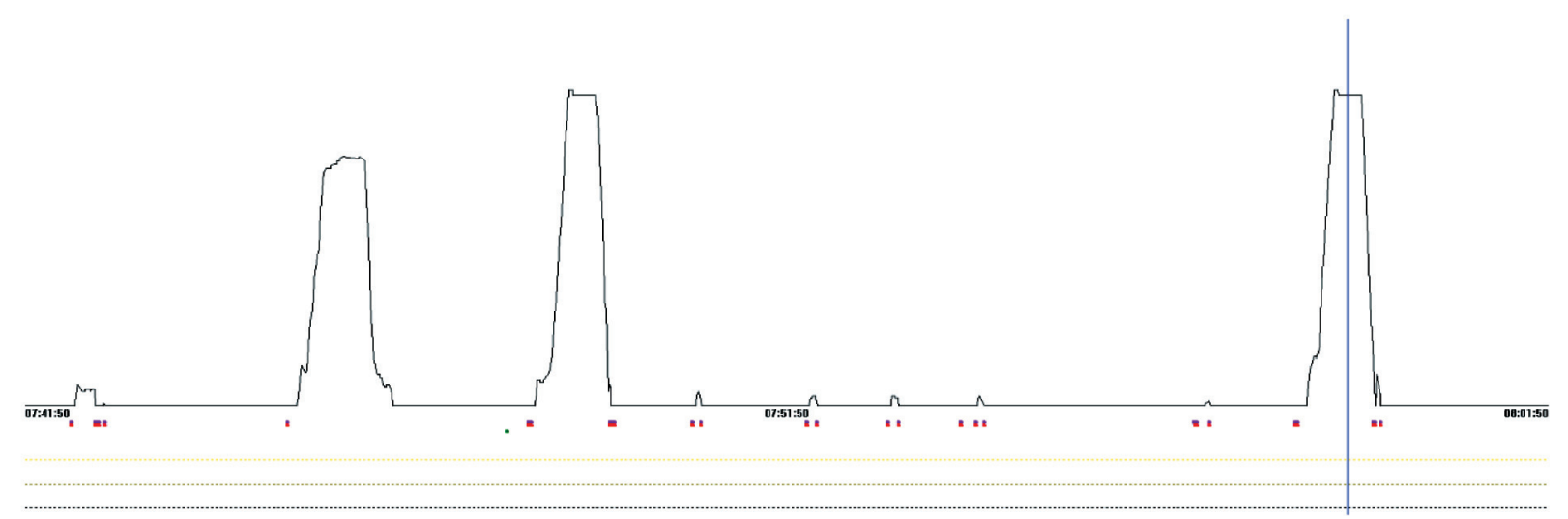

Fig. 2. Randomly selected recording of the travel speed - incorrect operation of the hoisting machine 


\section{CHANGES MADE}

\subsection{General characteristics}

A separate control unit based on MENTOR thyristor converters (Fig. 3) [3] was installed in the mine shaft hoist.

Scope of work:

- modernization of the excitation system of the control generator consisting in replacing the amplidyne with a reverse thyristor converter installed in the SWG cabinet (Fig. 4),

- modernization of the excitation system of the winding machine driving motor, consisting in replacing the electromechanical exciter with a thyristor converter installed in the SWM cabinet (Fig. 5).

Additionally, in order to stabilize the speed (especially during revision works in the shaft), the system of setting speed levels of the hoisting machine has been modified. Speed control was realized by a follow speed control system built on the basis of a digitally controlled MENTOR reverse converter.

\subsection{Thyristor excitation system of a control generator}

The MENTOR digital thyristor exciter operating in a reversing system (PWG) was used to supply the excitation windings of the control generator. The exciter is equipped with the SM Applications Plus module containing the processor.

The analogue input signals for the MENTOR MP exciter are:

- speed commanded from the rudder in the X direction,

- speed commanded from the rudder in the Y direction,

- main circuit current (through the SEJ separator),

- main circuit voltage proportional to the driving speed (through the SENV separator).

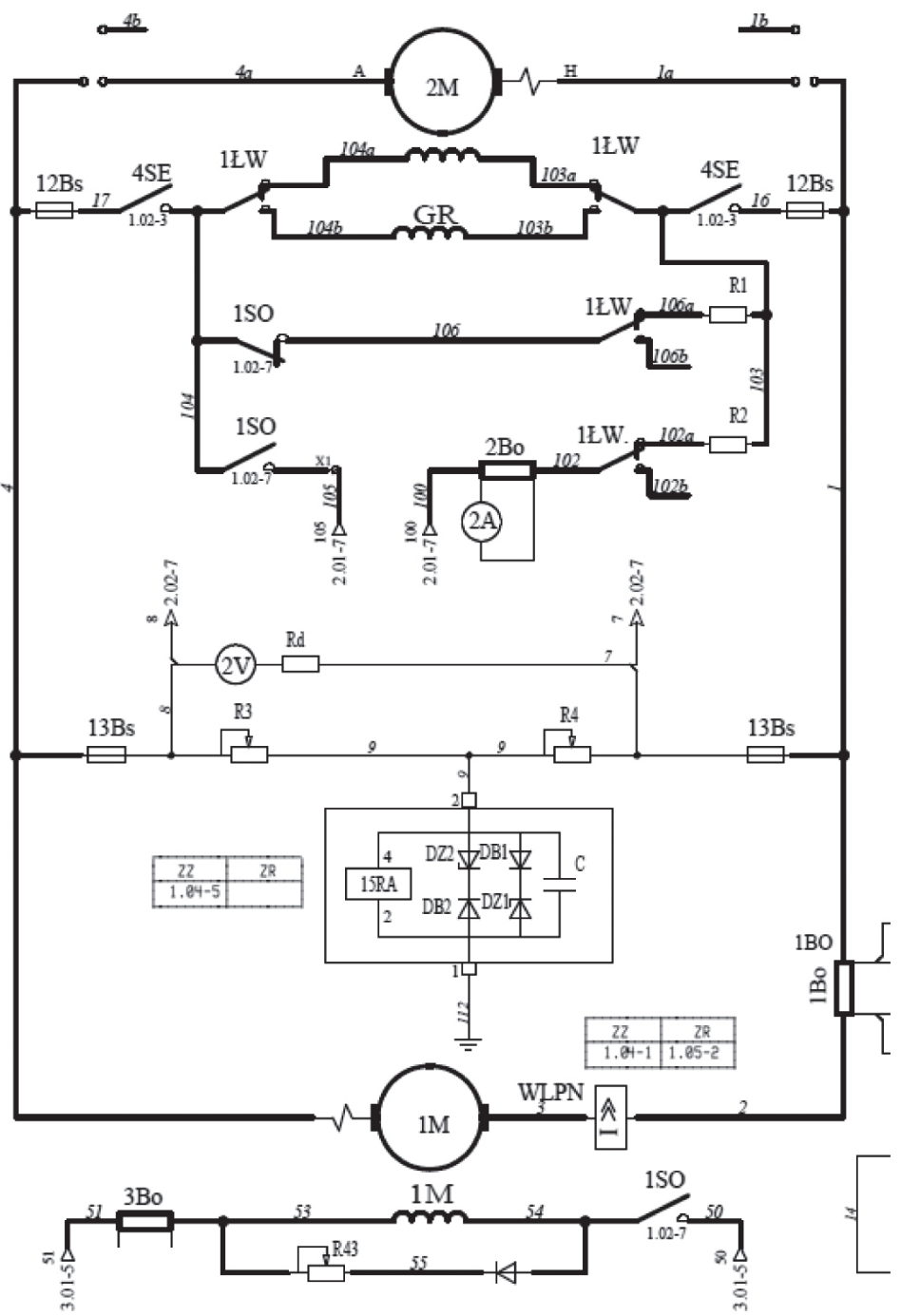

Fig. 3. Schematic diagram of the hoisting machine drive after introduced changes [4] 


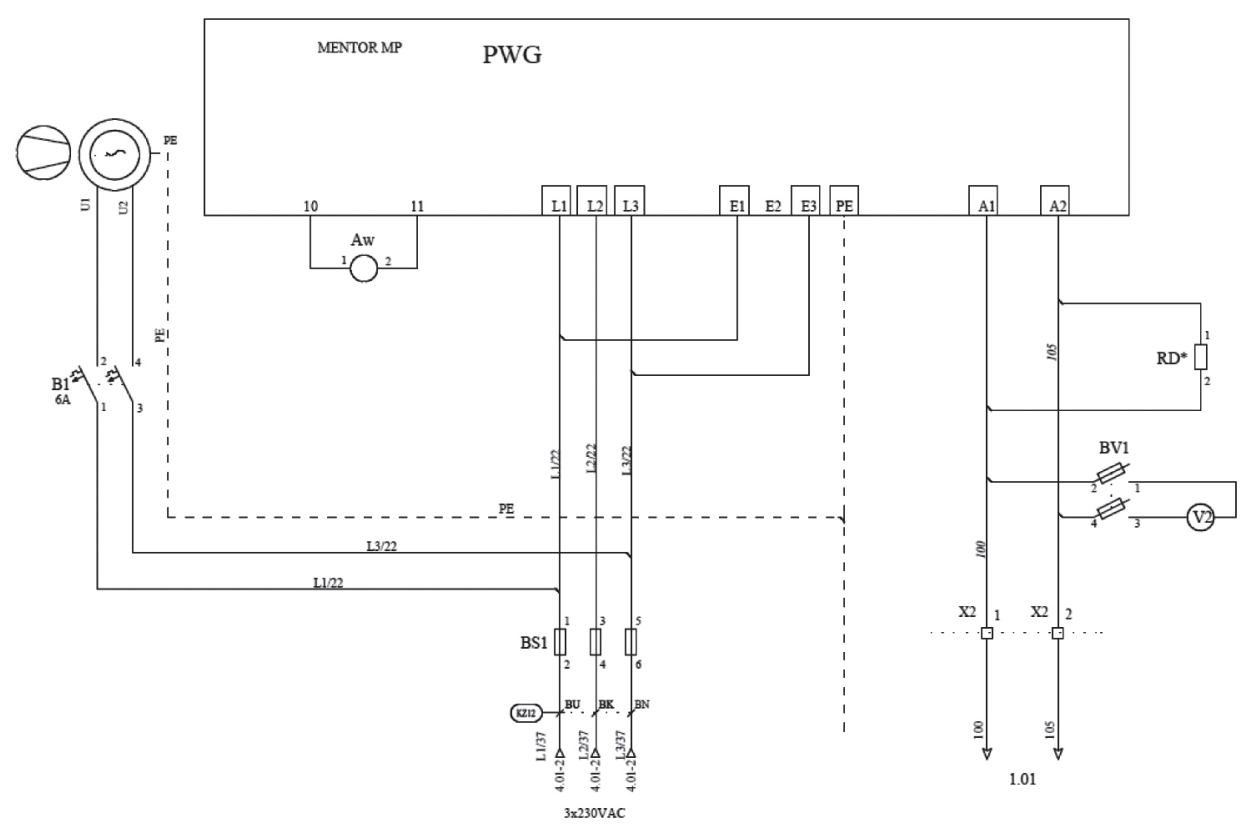

Fig. 4. Excitation of the control generator [4]

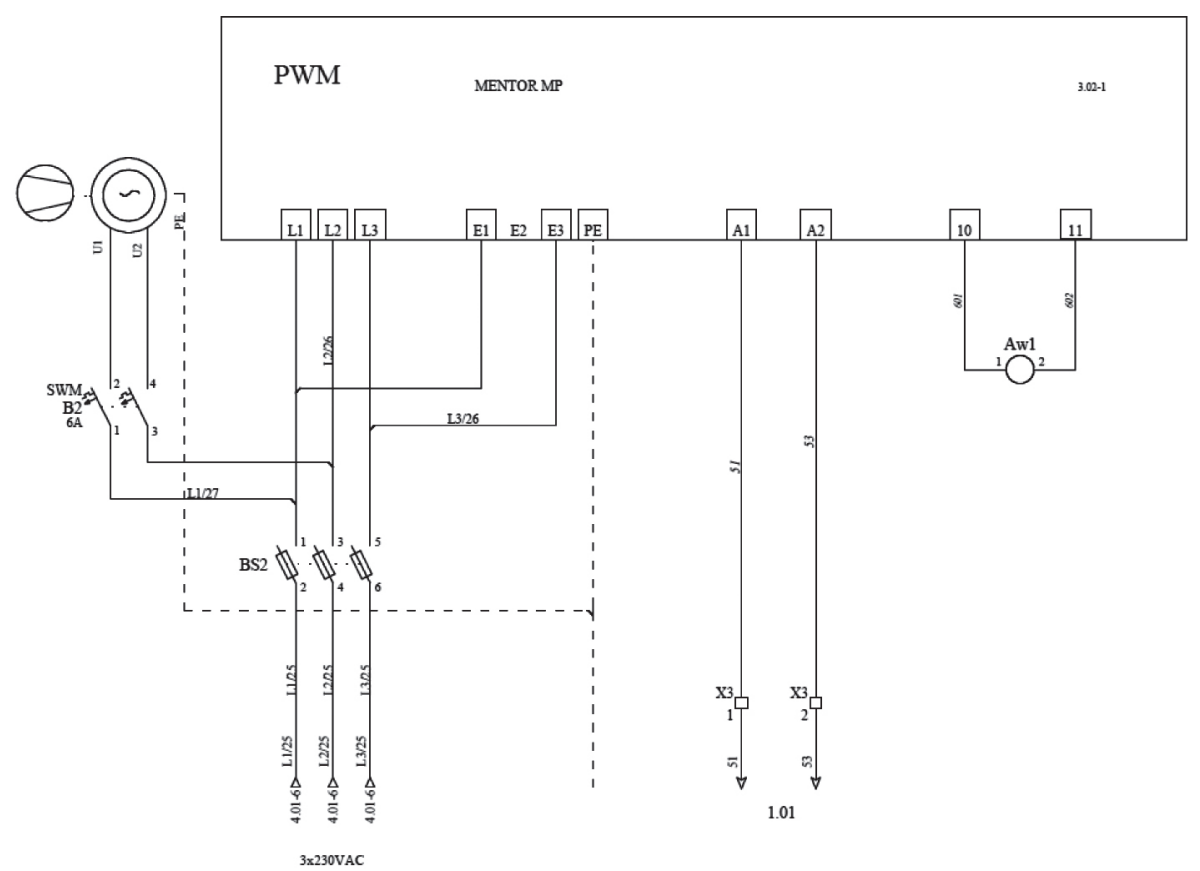

Fig. 5. Excitation of the driving motor of the hoisting machine [4]

The binary input signals for the MENTOR MP exciter are:

- signals about selecting the maximum speed,

- signal about switching on the safety circuit (PPHB),

- signal about breaking the hoisting machine (KCZ),

- converter protection memory erase signal (KSWG),

- signal about increasing the starting current limit when the machine is stopped (EZP).

Excitation of the control generator with the use of the MENTOR MP75A4R thyristor converter and the SM Applications Plus processor module will enable the following functions:

- setting the winding machine speed by the hoisting driver using the existing setpoint device and the existing travel controller,

- implementation of a speed controller based on speed feedback, which forms an input signal for the main circuit current controller based on the difference between the commanded speed and the actual speed. This controller can be proportional or proportional-integral, 
- limitation of the maximum travel speed depending on the type of work included in the shaft signalling and communication device,

- limitation of the maximum accelerations and decelerations set by the control system, independently of the position of the cages in the shaft,

- implementation of the main circuit current controller based on the current feedback from the actual main circuit current, which, based on the difference between the set current and the actual current, creates an input signal for the excitation current controller of the control generator.

The MENTOR MP converter software enables the introduction of a step change of the signal to the speed setting inputs. These are inputs with the socalled "ramp", which enables a gradual increase of the set value for the speed controller and the limitation of the maximum accelerations and decelerations set by the control system. The system also makes it possible to limit the travel speed depending on the type of work enabled in the shaft signalling device.

The speed controller implemented in the exciter may be a proportional $\mathrm{P}$ controller or a PI proportional-integral controller. When setting the speed, right after the brake release, the speed controller is a proportional $\mathrm{P}$ controller, which enables the precise setting of the main circuit current by the hoist driver as a function of the rudder stick deflection angle. After exceeding the set speed threshold, the controller is adapted to a PI controller, which reduces the speed error to zero. Working with the PI controller ensures the same access roads and access speeds, regardless of the transported weight, which significantly improves the safety of the lift during an emergency stop [1].

Speed measurement is performed indirectly by measuring the voltage of the main circuit. This voltage is practically proportional to the rotational speed of the drive motor and, using the capabilities of the thyristor exciter processor, is continuously converted into hoist speed. The main circuit voltage is fed through the SENV separator to the analogue input of the exciter.

\subsection{Speed setting system}

The speed setting system is based on the existing 1TS mechanical-cam control rod. The 1TS control output is input independently for each direction of travel to two voltage separators SEN1 and SEN2, and then to two analogue inputs of the PWG exciter. The set speed signal takes into account the operation of the mechanical travel regulator in the machine. The maximum speed selection system is used to limit the value of the maximum speed set by the rudder, depending on the type of work included in the shaft signalling and communication device, as shown in Figure 1.

\subsection{Thyristor excitation system of the drive motor}

The MENTOR digital thyristor exciter operating in a unidirectional system, marked with the PWM symbol, is used to supply the excitation winding of the drive motor of the hoisting machine. Based on the input signals, when the hoisting machine is released, the excitation current increases to the nominal value. The maximum speed of the excitation current increase is ensured by an appropriate forcing factor. After braking the machine, the excitation current is reduced in order to limit active power losses [4].

\section{GENERAL CHARACTERISTICS OF THE MENTOR MP THYRISTOR CONVERTER}

The Mentor MP is the latest version of a modern digital DC rectifier with a 6-pulse output waveform (optional configuration (series) gives a 12-pulse waveform). The fully programmable rectifier offers great flexibility when integrating the control system. It is equipped with a rich set of functions, ensuring the quick and easy configuration of system settings. The easy-to-use system features include programmable analogue and digital $\mathrm{I} / \mathrm{O}$, digital master-controlled and dependent current limits, among others. Other advanced features include serial communication and threshold value programming. It is used in applications requiring energy return to the grid, high system dynamics and a constant torque or power value in a wide speed range [3].

\section{CONCLUSIONS}

The presented example of the solution allowed us to increase the operational safety and reliability of the mine shaft hoist. 
In connection with the renovation of the control system of the hoisting machine of the mine shaft hoist in the cage compartment of the "Sobieski III" shaft of Tauron Wydobycie S.A. Z.G. Sobieski, the following benefits were obtained:

- the modernization carried out did not interfere with the normal operation of the shaft, regular travel of people, extraction and revision works were carried out in accordance with the shaft work schedule,
- the proposed system improved the dynamics of the drive, which allowed the elimination of overshoots (Fig. 6),

- the machine was allowed to operate at concession speeds, which made it possible to shorten the duration of cycles and increase production,

- the motors driving the exciters and the amplidyne were switched off, which allowed for energy savings,

- expenditures on repairs and maintenance (brushes, commutator, bearings, inspections performed by specialized companies) were reduced.

Travel of people, $\mathrm{X}$ direction, $\mathrm{Q}=6 \mathrm{Mg}$ up

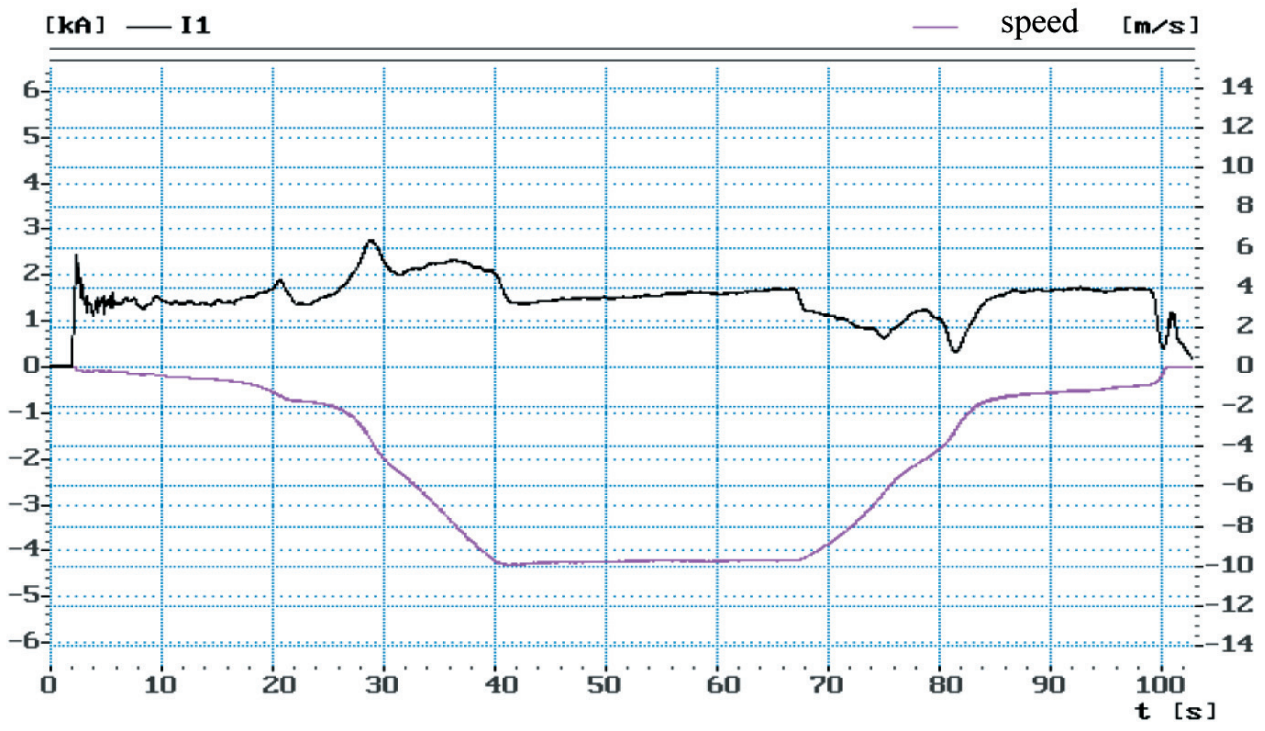

Output, $\mathrm{Y}$ direction, $\mathrm{Q}=6 \mathrm{Mg}$ down

[kA] $-\mathrm{I} 1$

- speed $[\mathrm{m} / \mathrm{s}]$

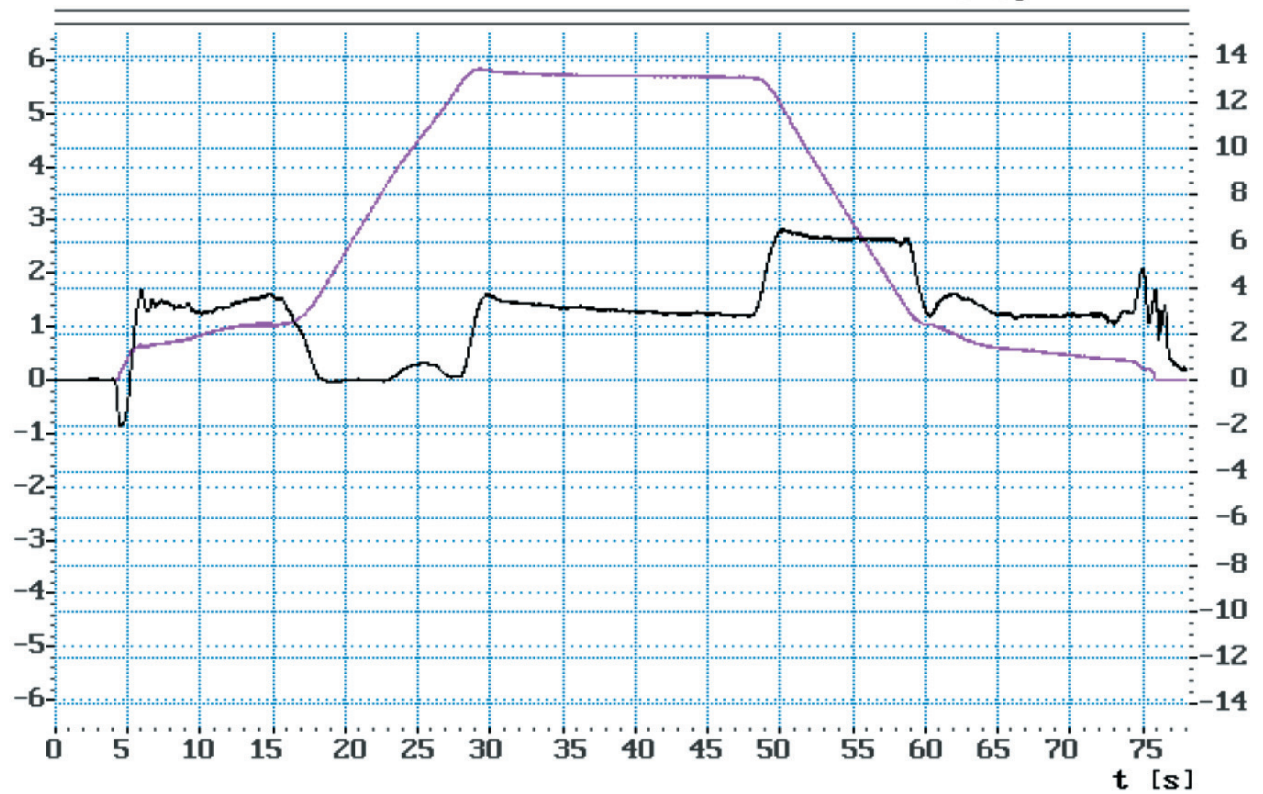

Fig. 6. Randomly selected speed registrations - correct operation of the hoisting machine after the introduced changes 


\section{References}

[1] Szklarski L., Zarudzki J.: Elektryczne maszyny wyciagowe, Wydawnictwo Naukowe PWN, Warszawa - Kraków 1998.

[2] Operation and maintenance manual of the presented hoisting machine [unpublished].

[3] User manual, Basic version, Mentor MP, Thyristor digital drive for DC motors, Catalogue number; 0476-0003-02, Issue: 2 [trial version].

[4] Documentation provided by PPUH "ELCAM" Sp. z o.o. in Świętochłowice [unpublished].
ROMAN GASSKA, MSc., Eng. ZBIGNIEW WOLNY, MSc., Eng. MARIUSZ MYRLAK, MSc., Eng. MARCIN KRUK, MSc., Eng. TOMASZ KARPIEL, PhD., Eng.

Tauron Wydobycie S.A. Z.G. Sobieski ul. Sulińskiego 2, 43-600 Jaworzno, Poland tomasz.karpiel@tauron-wydobycie.pl

(C) 2019 Authors. This is an open access publication, which can be used, distributed and reproduced in any medium according to the Creative Commons CC-BY 4.0 License. 


\title{
Poprawa bezpieczeństwa pracy i zwiększenie funkcjonalności prowadzenia ruchu w górniczym wyciągu szybowym (Tauron Wydobycie S.A. Z.G. Sobieski)
}

\begin{abstract}
$W$ artykule przedstawiono informację na temat zmian górniczego wyciagu szybowego w przedziale klatkowym szybu „Sobieski III” Tauron Wydobycie S.A. Z.G. Sobieski. $W$ uktadzie wzbudzenia silnika napędowego oraz prądnic sterujacych zainstalowano wyodrębniony zespót sterowniczy oparty na przeksztaltnikach tyrystorowych MENTOR, co pozwolito zastapić układy kłopotliwe w eksploatacji, m.in. wzmacniacz elektromaszynowy (amplidyna) oraz wzbudnice maszynowa silnika wyciagowego. Dodatkowo $w$ celu zapewnienia stabilizacji prędkości (szczególnie podczas prac rewizyjnych $w$ szybie), zostat zmodyfikowany układ zadawania poziomów prędkości maszyny wyciagowej. Regulacja prędkości jest zrealizowana przez nadą̇ny uktad regulacji prędkości zbudowany w oparciu o cyfrowo sterowany przeksztattnik rewersyjny MENTOR.
\end{abstract}

Słowa kluczowe: górnicze wyciagi szybowe, modernizacja, maszyna wyciagowa, bezpieczeństwo, układ sterowania

\section{CHARAKTERYSTYKA OGÓLNA}

Prezentowana maszyna wyciagowa jest elementem górniczego wyciągu szybowego: dwunaczyniowego, klatkowego, przeznaczonego do jazdy ludzi, transportu materiałów i wydobycia, zainstalowana w pomieszczeniu na zrębie. Maszyna wyciągowa sterowana jest ręcznie, współpracuje $\mathrm{z}$ urządzeniem sygnalizacji i łączności szybowej. Napęd maszyny wyciągowej stanowi obcowzbudny silnik prądu stałego, zasilany z elektromaszynowej prądnicy sterującej, pracujący w układzie Leonarda. Zmianę kierunku obrotów silnika uzyskuje się przez zmianę kierunku prądu wzbudzenia prądnicy sterującej [1].

Drążek sterowniczy na stanowisku sterowniczym maszyny wyciągowej jest połączony z mechanicznym regulatorem jazdy, wskaźnikiem głębokości - szybowskazem i zadajnikiem indukcyjnym. Kąt wychylenia steru jazdy jest ograniczony mechanicznie krzywkami w funkcji położenia naczyń wyciągowych [2]. Całościowy schemat układu zadawania prędkości został przedstawiony na rysunku 1 .

Nieregularne zmiany rezystancji w układzie wyboru prędkości, wskutek odziaływania temperatury zewnętrznej (wynik starzenia się elementów), powodowały zmianę sygnału zadającego, co w połączeniu z inercyjnym charakterem układu regulacji skutkowało:

- niestabilną pracą,

- przeregulowaniem prędkości,

- nieliniowością diagramu jazdy.

To wszystko spowodowało, że parametry jazdy były niższe od koncesyjnych, co wydłużyło czas trwania cyklu jazdy. Skutek ekonomiczny takiego stanu był zauważalny ze względu na zmniejszenie wydobycia.

Na rysunku 2 przedstawiono przykładową, losowo wybraną, rejestrację pracy maszyny. Widoczne są stany niestabilnej pracy polegające na przeregulowaniach oraz nieliniowym diagramie jazdy. 

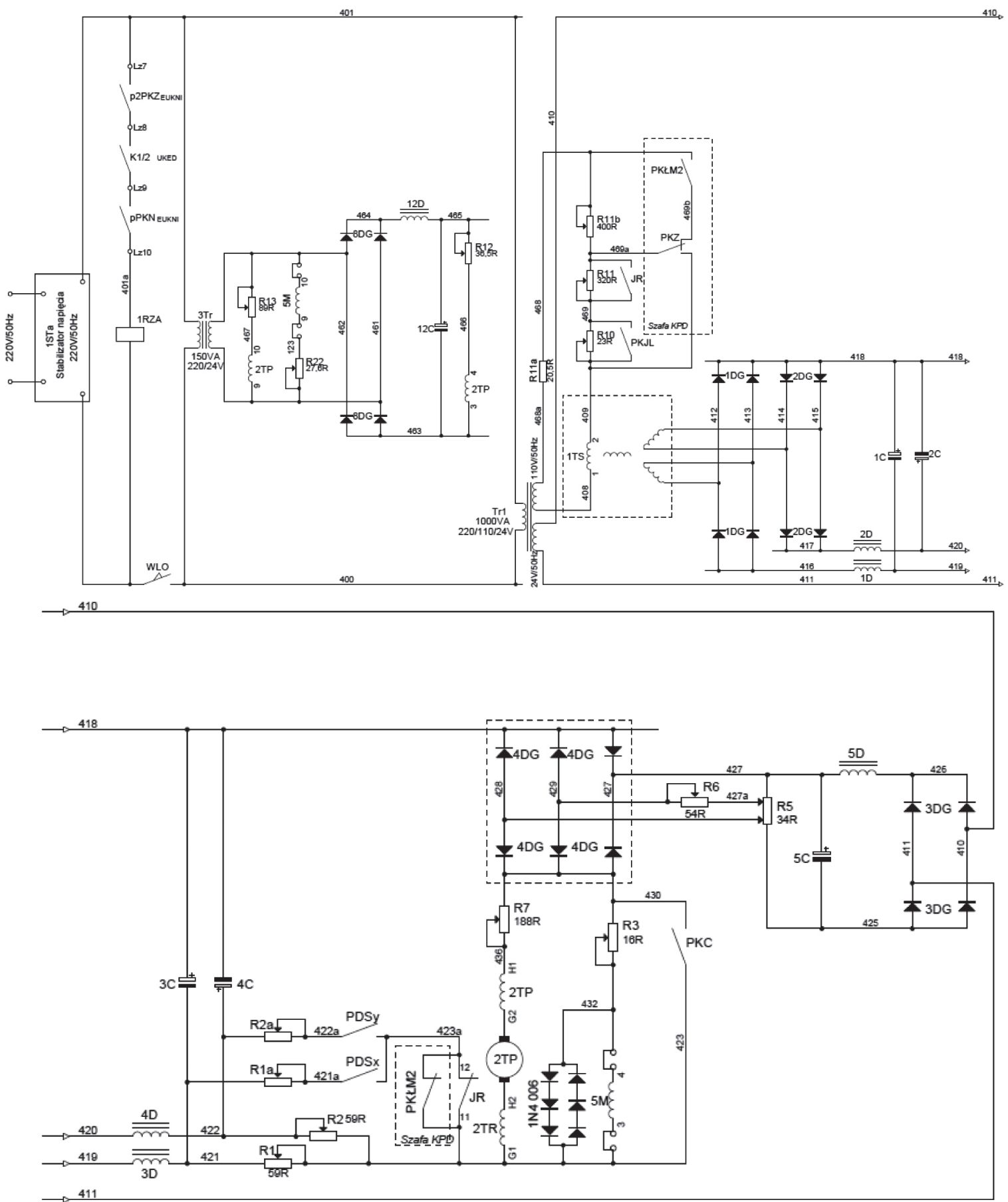

Rys. 1. Schemat zasadniczy układu zadawania prędkości wraz z układem wyboru prędkości maksymalnej [2]

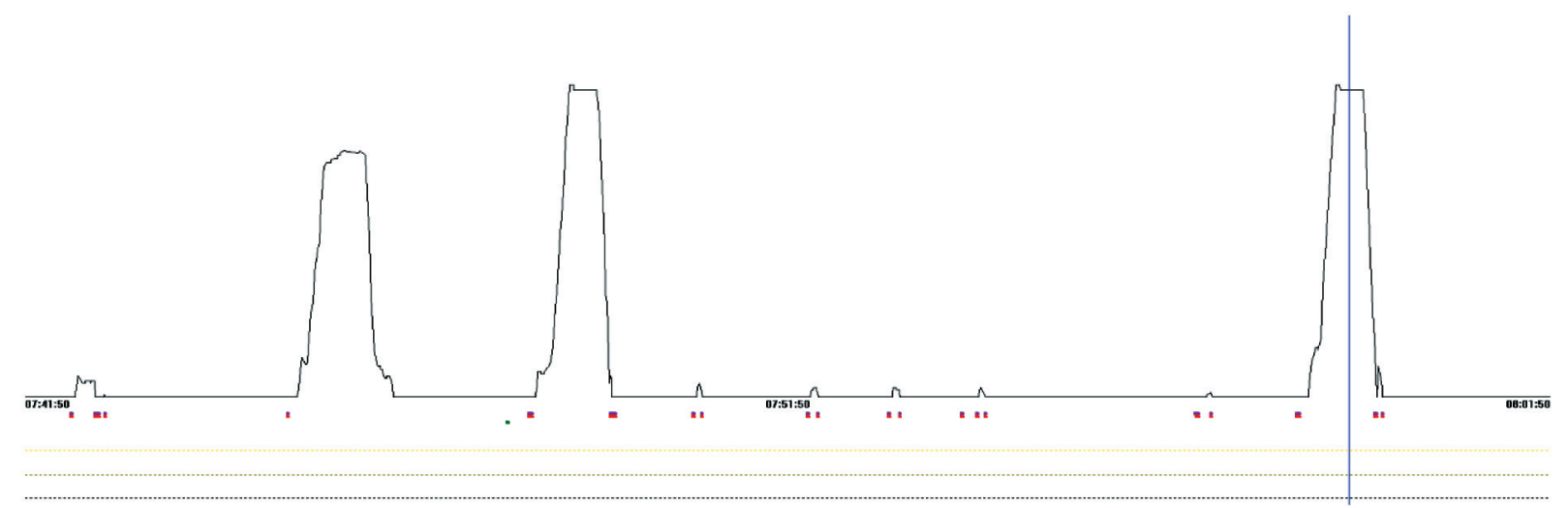

Rys. 2. Losowo wybrana rejestracja prędkości jazdy - nieprawidłowa praca maszyny wyciagowej 


\section{WPROWADZONE ZMIANY}

\subsection{Charakterystyka ogólna}

W górniczym wyciagu szybowym zainstalowano wyodrębniony zespół sterowniczy oparty na przekształtnikach tyrystorowych MENTOR (rys. 3) [3].

Zakres prac:

- modernizacja układu wzbudzenia prądnicy sterującej polegająca na zastąpieniu amplidyny przez rewersyjny przekształtnik tyrystorowy zabudowany w szafie SWG (rys. 4),

- modernizacja układu wzbudzenia silnika napędowego maszyny wyciagowej polegająca na zastąpieniu wzbudnicy elektromaszynowej przez przekształtnik tyrystorowy zabudowany w szafie SWM (rys. 5).

Dodatkowo w celu zapewnienia stabilizacji prędkości (szczególnie podczas prac rewizyjnych w szybie) został zmodyfikowany układ zadawania poziomów prędkości maszyny wyciągowej. Regulację prędkości zrealizowano przez nadążny układ regulacji prędkości z wykorzystaniem cyfrowo sterowanego przekształtnika rewersyjnego MENTOR.

\subsection{Układ tyrystorowego wzbudzenia prądnicy sterującej}

Do zasilania uzwojeń wzbudzenia prądnicy sterującej wykorzystano cyfrową wzbudnicę tyrystorową MENTOR pracującą w układzie nawrotnym (PWG). Wzbudnica wyposażona jest w moduł SM Applications Plus zawierający procesor.

Analogowymi sygnałami wejściowymi dla wzbudnicy MENTOR MP są:

- prędkość zadana ze steru jazdy w kierunku X,

- prędkość zadana ze steru jazdy w kierunku Y,

- prąd obwodu głównego (przez separator SEJ),

- napięcie obwodu głównego proporcjonalne do prędkości jazdy (przez separator SENV).

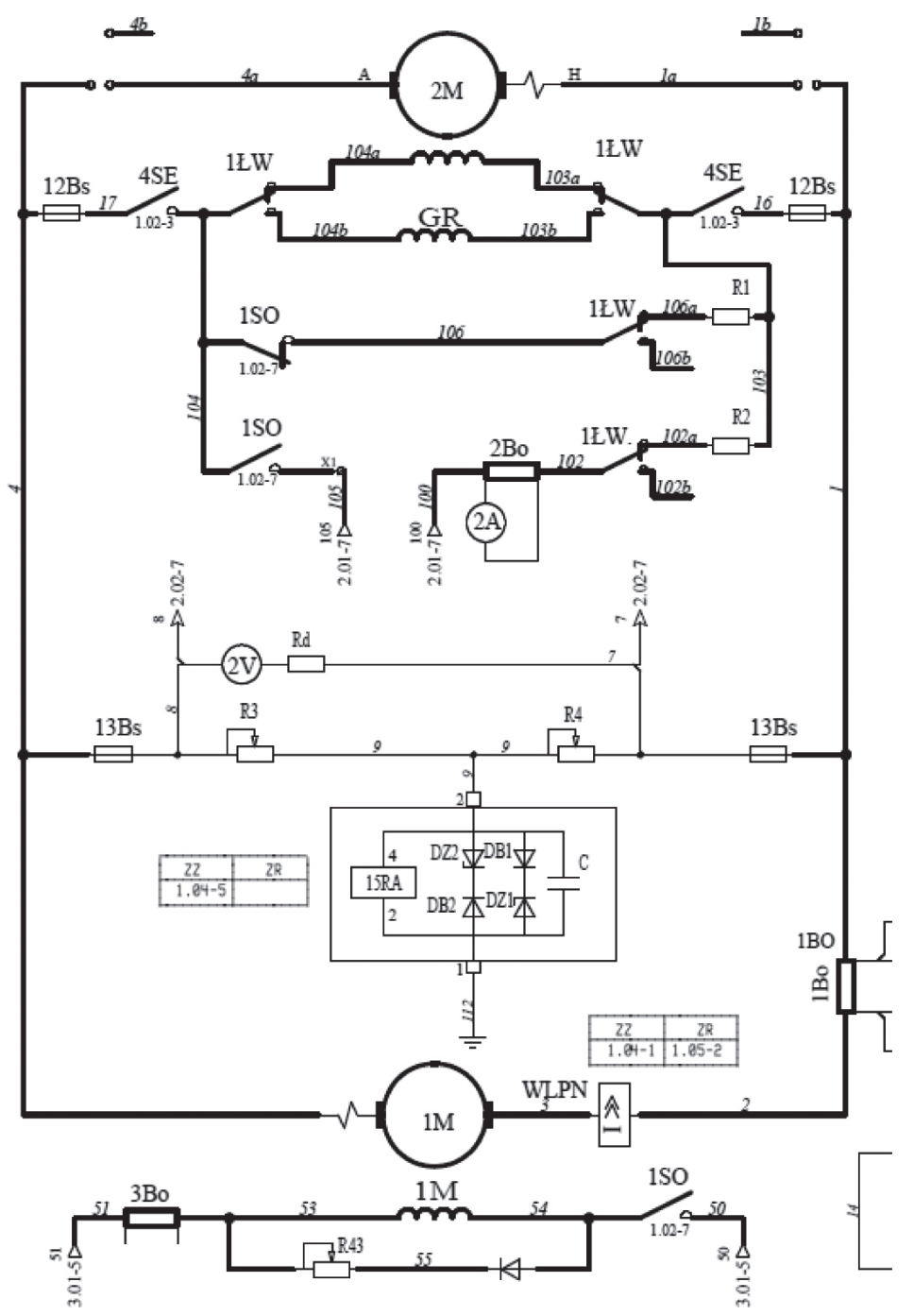

Rys. 3. Schemat ideowy napędu maszyny wyciagowej po wprowadzonych zmianach [4] 


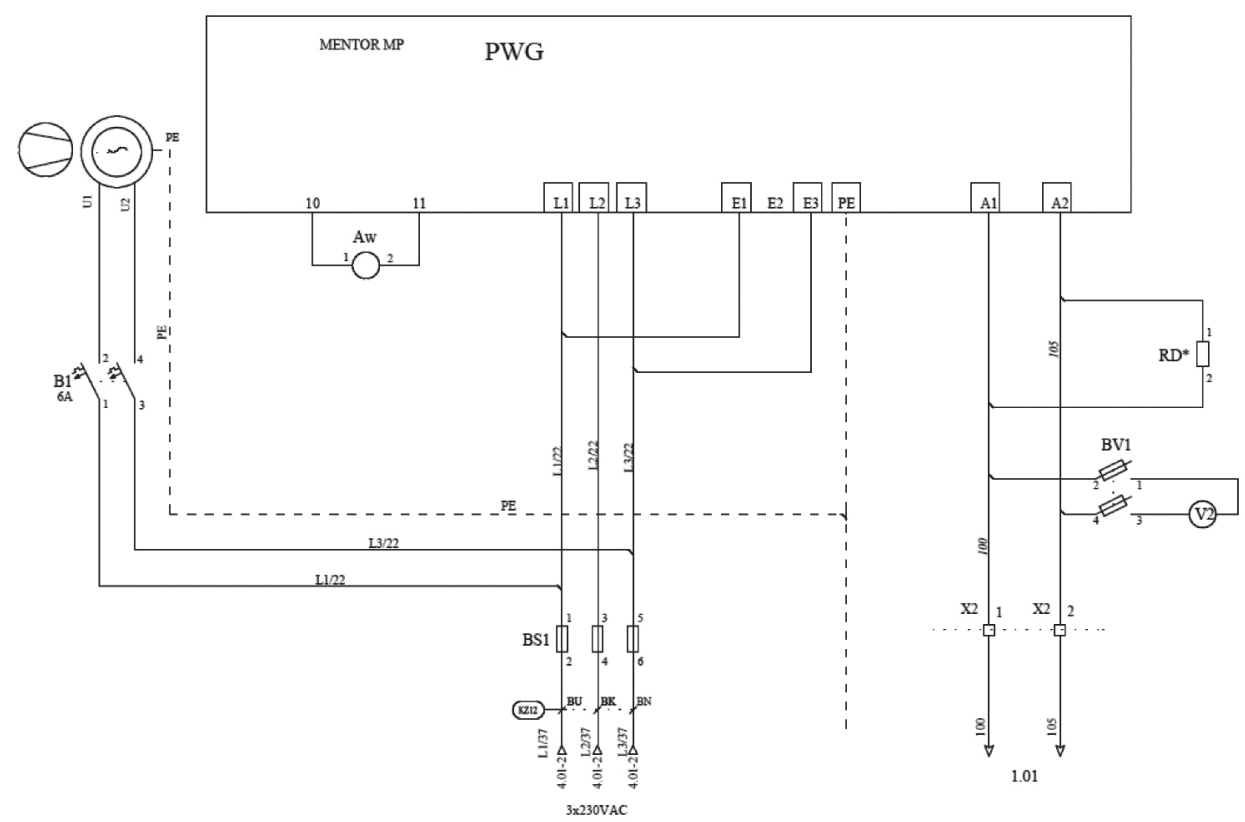

Rys. 4. Wzbudzenie pradnicy sterującej [4]

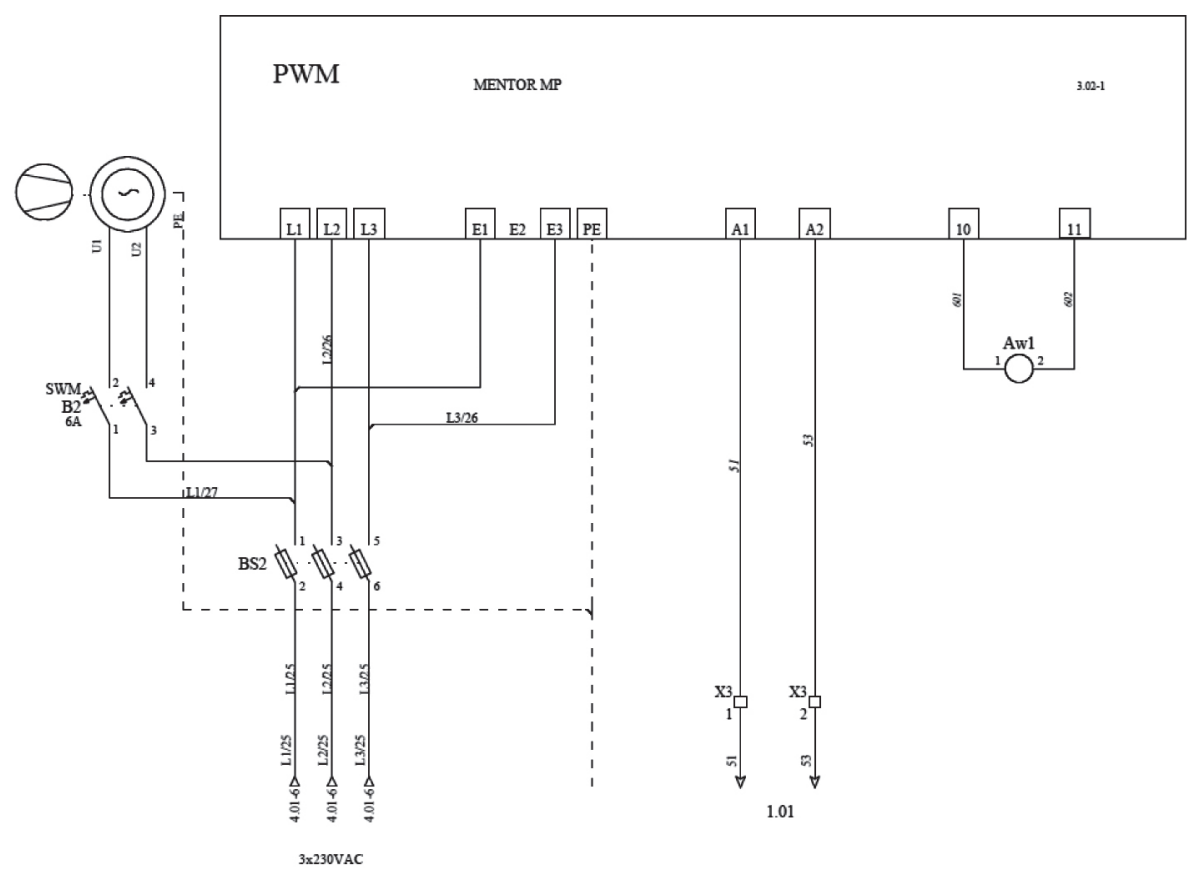

Rys. 5. Wzbudzenie silnika napędowego maszyny wyciagowej [4]

Binarnymi sygnałami wejściowymi dla wzbudnicy MENTOR MP są:

- sygnały o wyborze prędkości maksymalnej,

- sygnał o załączeniu obwodu bezpieczeństwa (PPHB),

- sygnał o zahamowaniu maszyny wyciagowej (KCZ),

- sygnał kasowania pamięci zabezpieczeń przekształtnika (KSWG),

- sygnał o zwiększeniu pułapu prądu startowego przy zatrzymanej maszynie (ŁZP).

Wykonanie wzbudzenia prądnicy sterującej z wykorzystaniem przekształtnika tyrystorowego typu MENTOR
MP75A4R oraz modułu procesora SM Applications Plus umożliwi realizację takich funkcji, jak:

- zadawanie prędkości maszyny wyciągowej przez maszynistę wyciągowego z wykorzystaniem istniejącego zadajnika oraz istniejącego regulatora jazdy,

- oparta na sprzężeniu prędkościowym realizacja regulatora prędkości, który na podstawie różnicy między prędkością zadaną a rzeczywistą tworzy sygnał wejściowy dla regulatora prądu obwodu głównego - regulator ten może być proporcjonalny lub proporcjonalno-całkujący, 
- ograniczenie maksymalnej prędkości jazdy w zależności od załączonego rodzaju pracy w urządzeniu sygnalizacji i łączności szybowej,

- ograniczenie maksymalnych przyspieszeń i opóźnień zadawanych przez układ regulacji w sposób niezależny od położenia naczyń w szybie,

- realizacja regulatora prądu obwodu głównego oparta na sprzężeniu prądowym od rzeczywistego prądu obwodu głównego, który na podstawie różnicy między prądem zadanym a rzeczywistym tworzy sygnał wejściowy dla regulatora prądu wzbudzenia prądnicy sterującej.

Oprogramowanie przekształtnika MENTOR MP umożliwia wprowadzenie skokowej zmiany sygnału na wejścia zadające prędkość jazdy. Są to wejścia z tzw. rampą, co umożliwia stopniowy narost wartości zadanej dla regulatora prędkości oraz ograniczenie maksymalnych przyspieszeń i opóźnień zadawanych przez układ regulacji. Układ też umożliwia ograniczenie wartości prędkości jazdy w zależności od załączonego rodzaju pracy urządzenia wyciągowego.

Regulator prędkości zrealizowany we wzbudnicy może być regulatorem proporcjonalnym P lub regulatorem proporcjonalno-całkującym PI. Przy zadawaniu prędkości, zaraz po odhamowaniu, regulator prędkości jest regulatorem proporcjonalnym $\mathrm{P}$, który umożliwia precyzyjne zadawanie prądu obwodu głównego przez maszynistę wyciągowego wprost proporcjonalnie do kąta wychylenia drążka dźwigni steru. Po przekroczeniu zadanego progu prędkości regulator jest adaptowany na regulator PI, który redukuje błąd prędkości do zera. Praca z regulatorem PI zapewnia zachowanie tych samych dróg dojazdowych i prędkości dojazdowych niezależnie od transportowanego ciężaru, co znacznie poprawia bezpieczeństwo wyciągu podczas awaryjnego zatrzymania [1].

Pomiar prędkości jest realizowany w sposób pośredni przez pomiar napięcia obwodu głównego. Napięcie to jest praktycznie proporcjonalne do prędkości obrotowej silnika napędowego i z wykorzystaniem możliwości procesora wzbudnicy tyrystorowej jest w sposób ciągły przeliczane na prędkość wyciągu. Napięcie obwodu głównego przez separator SENV jest wprowadzane na wejście analogowe wzbudnicy.

\subsection{Układ zadawania prędkości}

Układ zadawania prędkości został oparty na istniejącym mechaniczno-krzywkowym drążku sterowni- czym 1TS. Sygnał wyjściowy ze steru jazdy 1TS jest wprowadzony niezależnie dla każdego kierunku jazdy na dwa separatory napięciowe SEN1 i SEN2, a następnie na dwa wejścia analogowe wzbudnicy PWG. Sygnał prędkości zadanej uwzględnia działanie istniejącego w maszynie mechanicznego regulatora jazdy. Układ wyboru prędkości maksymalnej służy do ograniczenia wartości prędkości maksymalnej zadawanej sterem jazdy w zależności od rodzaju pracy załączonego w urządzeniu sygnalizacji i łączności szybowej, co zostało przedstawione na rysunku 1 .

\subsection{Układ tyrystorowego wzbudzenia silnika napędowego}

Do zasilania uzwojenia wzbudzenia silnika napędowego maszyny wyciągowej służy cyfrowa wzbudnica tyrystorowa MENTOR pracująca w układzie jednokierunkowym, oznaczona symbolem PWM. Na podstawie sygnałów wejściowych w momencie odhamowania maszyny wyciągowej prąd wzbudzenia narasta do wartości znamionowej. Maksymalną prędkość narostu prądu wzbudzenia zapewnia odpowiedni współczynnik forsowania. Po zahamowaniu maszyny prąd wzbudzenia jest zmniejszany w celu ograniczenia strat mocy czynnej [4].

\section{CHARAKTERYSTYKA OGÓLNA PRZEKSZTALTNIKA TYRYSTOROWEGO MENTOR MP}

Mentor MP stanowi najnowszą wersję nowoczesnego cyfrowego prostownika prądu stałego o przebiegu wyjściowym sześciopulsowym (konfiguracja opcjonalna, szeregowa, daje przebieg dwunastopulsowy). W pełni programowalny prostownik zapewnia dużą elastyczność podczas integracji systemu sterowania. Zawiera mnóstwo funkcji zapewniających szybką i prostą konfigurację nastaw systemu. Łatwe w użyciu funkcje systemu obejmują między innymi programowane wejścia/wyjścia analogowe i cyfrowe, cyfrowe sterowane nadrzędne oraz zależne ograniczenia prądowe. Inne funkcje zaawansowane obejmują komunikację szeregową oraz programowanie wartości progowych. Stosowany jest w aplikacjach wymagających zwrotu energii do sieci, wysokiej dynamiki systemu oraz stałej wartości momentu lub mocy w szerokim zakresie prędkości [3]. 


\section{WNIOSKI}

Przedstawiony przykład rozwiązania pozwolił na zwiększenie pewności ruchowej i niezawodności górniczego wyciągu szybowego.

W związku z remontem układu sterowania maszyny wyciągowej górniczego wyciąu szybowego w przedziale klatkowym szybu „Sobieski III” Tauron Wydobycie S.A. Z.G. Sobieski uzyskano następujące korzyści:

- przeprowadzona modernizacja nie zakłóciła normalnego toku pracy szybu, regularna jazda ludzi, wydobycie i prace rewizyjne odbywały się zgodnie $\mathrm{z}$ harmonogramem pracy szybu,
- zaproponowany układ poprawił dynamikę napę$\mathrm{du}$, co pozwoliło wyeliminować przeregulowania (rys. 6),

- umożliwiono pracę maszyny z prędkościami koncesyjnymi, co pozwoliło skrócić czas trwania cykli i zwiększyć wydobycie,

- wyłączono z pracy silniki napędzające wzbudnicę i amplidynę, co umożliwiło osiągnięcie oszczędności energetycznych,

- zmniejszono nakłady na remonty i obsługę bieżącą (szczotki, komutator, łożyska, przeglądy wykonywane przez wyspecjalizowane firmy).

Jazda ludzi, kierunek X, Q = 6 Mg w górę

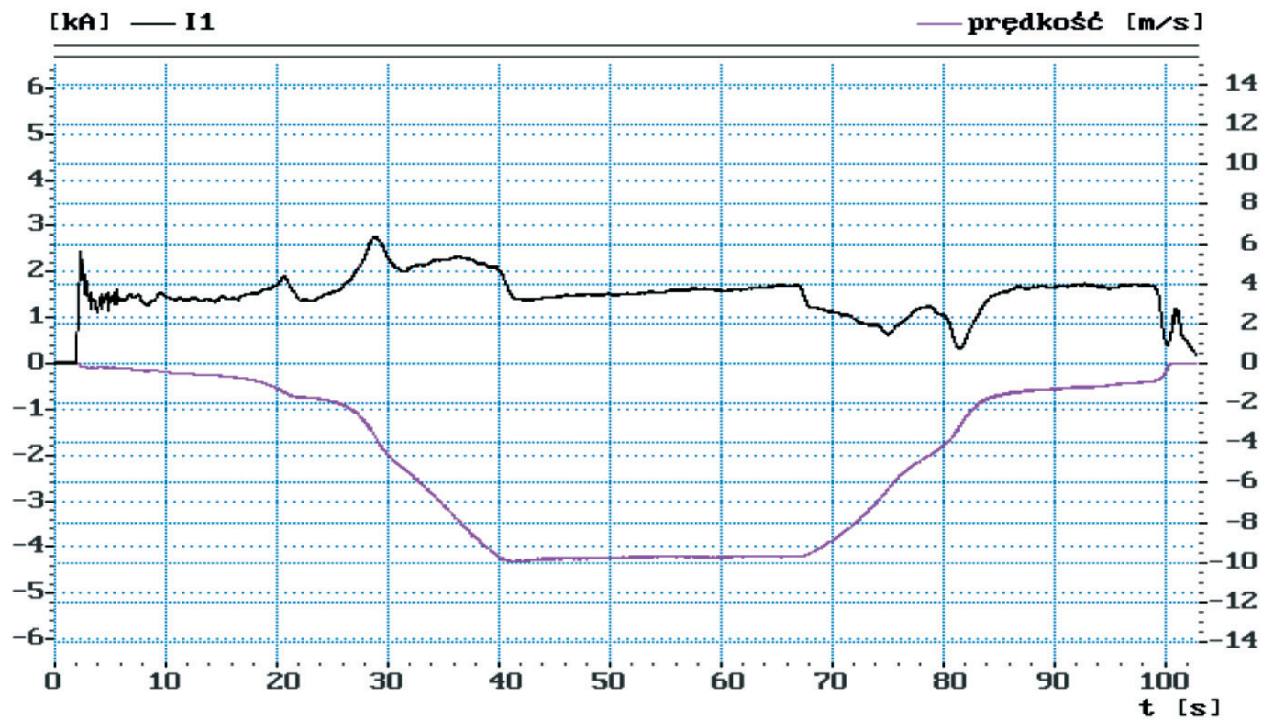

Wydobycie, kierunek $\mathrm{Y}, \mathrm{Q}=6 \mathrm{Mg}$ w dół

[kA] I I - prędkostc [m/s]

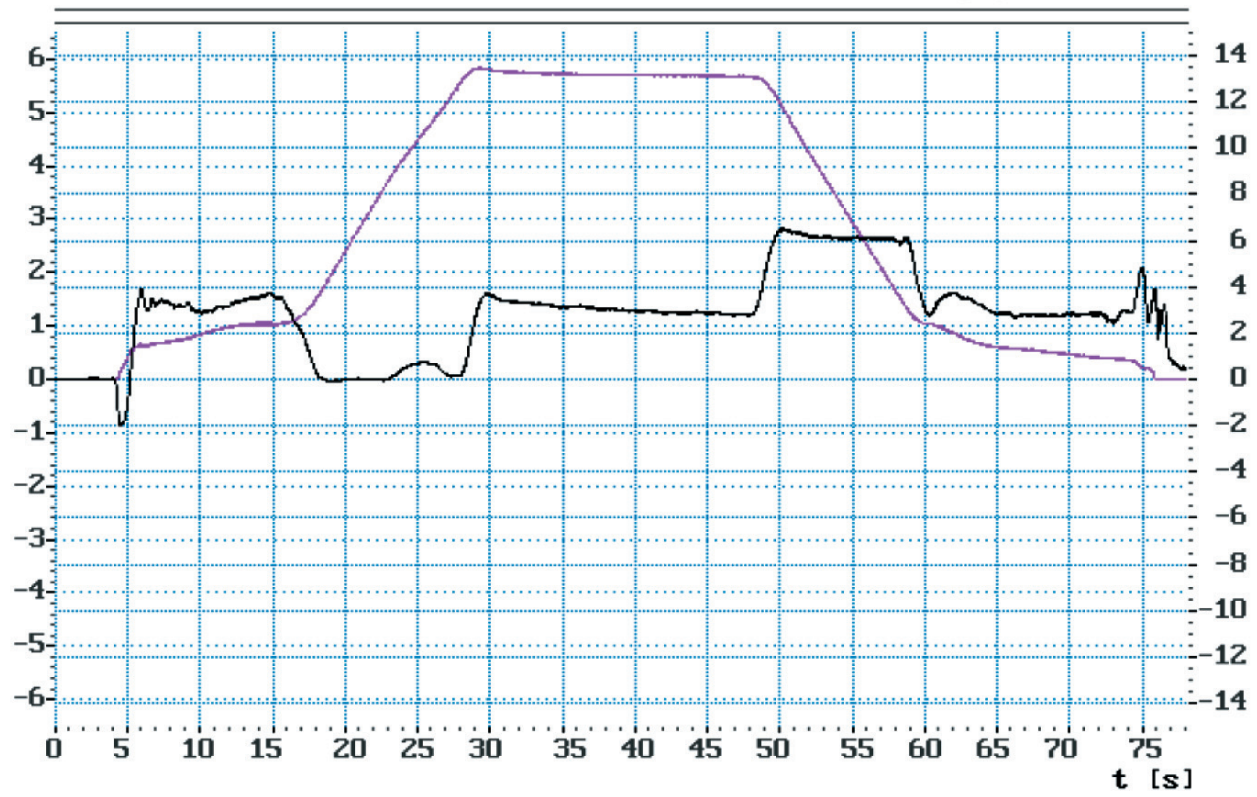

Rys. 6. Losowo wybrane rejestracje prędkości jazdy - prawidłowa praca maszyny wyciagowej po wprowadzonych zmianach 


\section{Literatura}

[1] Szklarski L., Zarudzki J.: Elektryczne maszyny wyciagowe, Wydawnictwo Naukowe PWN, Warszawa - Kraków 1998.

[2] Dokumentacja techniczno-ruchowa prezentowanej maszyny wyciągowej [niepublikowane].

[3] Podręcznik użytkownika, Wersja podstawowa, Mentor MP, Tyrystorowy cyfrowy napęd dla silników prądu stałego, Numer katalogowy; 0476-0003-02, wyd. 2 [wersja testowa].

[4] Dokumentacja udostępniona przez firmę PPUH „ELCAM” Sp. z o.o. w Świętochłowicach [niepublikowane]. mgr inż. ROMAN GACSKA mgr inż. ZBIGNIEW WOLNY mgr inż. MARIUSZ MYRLAK mgr inz. MARCIN KRUK dr inz. TOMASZ KARPIEL Tauron Wydobycie S.A. Z.G. Sobieski ul. Sulińskiego 2, 43-600 Jaworzno tomasz.karpiel@tauron-wydobycie.pl

(C) 2019 Autorzy. Jest to publikacja ogólnodostępna, którą można wykorzystywać, rozpowszechniać i kopiować w dowolnej formie zgodnie z licencją Creative Commons CC-BY 4.0. 